\title{
1. Pacific Migration and Transnationalism: Historical Perspectives
}

\section{Helen Lee}

\section{Introduction: Mobility Within and Beyond the Pacific Islands}

The area now known as the Pacific was settled from west to east in surges of movement between island groups over hundreds of years, eventually taking people as far as Hawai'i in the north, Rapanui/Easter Island in the east and Aotearoa/New Zealand in the south. Throughout this process people maintained networks of contact between some of the islands, travelling in various kinds of seagoing vessels. Epeli Hau'ofa (1993a) has described the pre-colonial Pacific, the area he prefers to call Oceania, as a 'sea of islands' within which people moved freely and frequently, created social networks, traded and exchanged goods, and at times engaged in conflict and attempted to exert dominance over one another. His depiction of the Pacific is constructed in opposition to the 'Western' perspective which emerged during the colonial period and emphasises the vastness of the Pacific Ocean and the small size and isolation of the areas of land dotted across it. The worldview Hau'ofa describes suggests a Pacific model of migration and transnationalism in which the ocean connects migrants to their homelands and is not regarded as a hindrance to their ongoing, enduring ties.

The early patterns of inter-island mobility, such as that between Tonga, Samoa and Fiji (Kaeppler 1978), continued and expanded once Europeans entered the Pacific and colonised all but Tonga. The colonial era afforded opportunities for movement within and beyond the Pacific, initially for men working on European and American vessels in the late $18^{\text {th }}$ century. By the mid $-19^{\text {th }}$ century a labour trade had emerged in which Islanders, mainly from what had become known as Melanesia, spread across the Pacific to work on plantations and into Queensland, Australia, to work in the sugar cane fields. Other Islanders found their way to port towns like Auckland in New Zealand, and Sydney in Australia, and settled there as the earliest Pacific migrants. Some of this movement was voluntary as people sought new ways to access the goods and money that were rapidly transforming their home economies, while some was part of the notorious 'blackbirding' in which people were taken against their will (Howe 1984). Movement between the islands also involved Islander missionaries, from the late $19^{\text {th }}$ century to mid $-20^{\text {th }}$ century, with the mainly east-west flow of these missionaries reversing the direction of the initial migrations into the Pacific. As 
Hau'ofa (1993b) has shown, these are just some of many forms of movement within the Pacific in the period before World War II.

The Pacific was the last region of the world to be affected by European and American imperialism and after World War II it was also the last region to undergo the often difficult process of decolonisation. This began in 1962 when Western Samoa (now Samoa) gained independence, and continued throughout the 1970s and '80s, although even today some of the islands are not fully independent. It was during this post-war era that people began to migrate from the Pacific in significant numbers and this movement was influenced by the colonial history of the islands. The USA and New Zealand opened pathways for migration for Islanders with whom they had colonial ties, whereas other nations with colonies in the Pacific, such as England, Germany and Australia, did not follow suit; in the case of French colonies there was significantly more movement of French settlers into these countries than of Islanders to France. To some extent this influenced the predominance of migration from the regions known as Polynesia and Micronesia, with far less movement from the region known as Melanesia in the Western Pacific.

Tonga is an unusual case in the Pacific because it was the only country that escaped colonisation. In the colonial era its main links were with Britain, of which it was a protectorate from 1900 to 1970, but there was no preferential treatment encouraging Tongans to move to England. However, even without any access to migration through colonial ties, Tongans have managed to migrate in significant numbers since the late 1960s, mainly to New Zealand, the United States, and Australia, keeping Tonga's population relatively stable since that time. There are now more Tongans living overseas than in Tonga, if the overseas-born are included, as is the case for many Pacific populations.

One of the most recent developments in Pacific migration has been a rapid increase in the mobility of Fijians and Indo-Fijians. Although Indo-Fijians began migrating to Canada and the USA in the mid-1960s and have also moved in large numbers to Australia and New Zealand, fewer indigenous Fijians migrated internationally until late in the $20^{\text {th }}$ century, when increasing political and economic problems in Fiji led to a surge in migration by both indigenous Fijians and Indo-Fijians (see Schubert, this volume). Migration from Fiji expanded rapidly in the aftermaths of the coups of 1987, 2000 and 2006. For example, Carmen Voigt-Graf cites Fiji's National Planning Office as claiming that 'over half of Fiji's stock of middle to high-level labor was lost over the 10 years following the 1987 coup through emigration' (2007, 149). However, migration from Fiji is not simply motivated by its political crises and Hannan describes the economic problems caused by downturns in the sugar and garment industries that also have motivated migration (2006; see also Stahl and Appleyard 2007). 
Mohanty provides a useful overview of the history of migration from Fiji, describing the "great waves" of outflow of skilled human resources during the 1980s and 1990s and again after May 2000' (2006, 111). This skilled migration has included nurses and other health workers migrating to a range of countries (Brown and Connell 2004; see Connell, this volume), and movement of Fijian soldiers working for the United Nations as peacekeepers and members of the British Army in Iraq (Connell 2006a, Mohanty 2006). Many former Fijian soldiers have found employment as security guards for private companies in the major Iraqi cities and other Fijians are employed in support roles in Kuwait, covering engineering, mechanical and information technologies (Connell 2006a, 67).

There also has been some movement of Fijians within the Pacific, working as temporary skilled migrants in many Pacific countries in a wide range of professions. Rokoduru (2006) provides an interesting case study of Fijians working in the Marshall Islands and Kiribati in 2002, most of whom were indigenous Fijians and most of whom were remitting. She found that they moved 'in order to make the most of better economic and social opportunities elsewhere, and that they have every intention of returning to Fiji' $(2006,184)$. Rokoduru concludes that 'the success and future of this trend of intra-regional migration in the Pacific rests largely on one crucial aspect of temporary labour migration: that it remains just that-temporary' (ibid, 185).

What follows is a brief overview of the patterns of Pacific Islander migration to the three main destination countries - New Zealand, the USA and Australia. ${ }^{1}$ This chapter also introduces the topic of transnationalism and surveys the literature on the Pacific that has addressed the many ties that have now been formed by Pacific peoples at home and abroad since the post-war migrations.

\section{Movement to Aotearoa/New Zealand}

New Zealand's role in the Pacific during the colonial era has shaped its history of migration, as have frequent changes in immigration policies over the years (Bedford 1984). In the post-war era New Zealand gave citizenship to people from the Cook Islands and Niue, which it had formally annexed at the beginning of the $20^{\text {th }}$ century, and Tokelau, which it had administered since 1926. The Cook Islands and Niue are now self-governing territories in free association with New Zealand, while Tokelau remains a non-self-governing country. Each of these countries continues to have close ties to New Zealand and so many people have used their citizenship to migrate that the populations remaining in the islands are now considerably smaller than the migrant and overseas-born populations living in New Zealand.

In contrast, Western Samoans did not gain citizenship rights in New Zealand. Samoa was split into Western Samoa and American Samoa during the colonial era and after a period of German rule, New Zealand administered Western Samoa 
on behalf of the League of Nations then the United Nations from 1918 until 1962, when it gained independence. Nevertheless, many Samoans have migrated to New Zealand, and the Samoan Quota was established in 1970, permitting 1100 Samoans to immigrate each year.

In the 1950s the New Zealand government began actively recruiting labourers from Pacific countries to work in its rapidly developing industrial and agricultural sectors and from the late 1960s formal work-permit schemes were introduced, first for Fijians then for Tongans and Western Samoans, mainly for work in agriculture and forestry. The scheme ended with the 1987 coup in Fiji (Bedford et al 2007, 257). New Zealand also tried a brief period of visa-free entry for some Pacific Islanders in 1986, however, the net migration from Fiji, Tonga and Western Samoa in the late 1980s was 'more than double the number during the previous five years' and this surge of immigrants led to the scheme being abandoned after only a few months (Stahl and Appleyard 2007, 23).

At that point the New Zealand government decided to shift immigration policy to favour skilled migrants, such as teachers, health professionals and others with a range of qualifications, and reduced migration options for unskilled workers. This was a significant change which has had an ongoing impact on the nature of Pacific Islanders' movement into New Zealand. Another shift in policy in 2002 introduced the Pacific Access Category (PAC), which allows 250 migrants from Tonga, 75 from Kiribati and 75 from Tuvalu, and, since 2003, a further 250 migrants from Fiji. These migrants are accepted under certain conditions, and a ballot system is used to decide which applicants are successful. As with the Samoan Quota, the number of applicants through PAC has fluctuated and at times the quotas have not been filled. In late 2006 New Zealand again shifted its migration policies towards the Pacific and reopened access for seasonal agricultural workers, including those from Melanesia, first through the Seasonal Work Permit Policy (Stahl and Appleyard 2007, 35) then most recently the Recognised Seasonal Employer (RSE) scheme, specifically aimed at eligible Pacific Islands Forum member nations and offering 5,000 places per year (Department of Labour, 2007).

In addition to the Pacific Islanders who have entered New Zealand under these various policies and schemes, others have settled in New Zealand as illegal immigrants, or 'overstayers.' This became a contentious issue in the 1970s and although the New Zealand government responded with heavy-handed tactics for removing those that could be found, it also held amnesties that enabled many to gain permanent residence and remain in the country. Today, the many pathways that have led Pacific Islanders to New Zealand have resulted in a 'Pasifika' population in which Samoans are the largest group, followed by Cook Islanders, Tongans, Niueans, Fijians and Tokelauans (Stahl and Appleyard 2007, 22). 


\section{Movement to Australia}

Australia did not instigate any preferential treatment for Papua New Guineans, despite its colonial ties to that country, nor did it assist migration from the countries of origin of the 'South Sea Islanders' (or 'Kanaks') working in the sugar plantations of Queensland. More generally, Australia tended to discourage migration from the Pacific through its 'White Australia' policy, in place from 1901 to 1973, and an emphasis on skilled migration. Nevertheless, there has been significant migration into Australia from the Pacific by various means, particularly the Trans-Tasman Travel Arrangement (TTTA) which allowed Australians and New Zealanders to move easily between the two countries to visit, live and work. Many pakeha and Maori New Zealanders have taken advantage of this arrangement to move to Australia, as have many Pacific Islanders, who first became citizens of New Zealand.

The TTTA has generated considerable tension between Australia and New Zealand over the years, particularly when New Zealand instituted amnesties for Pacific overstayers and work schemes for unskilled and low-skilled Islanders. Australia was concerned that this would lead to poorly skilled Islanders entering the country and circumventing its stringent, skills-based immigration policies (Bedford et al. 2007, 258). By the end of the $20^{\text {th }}$ century this tension led to a review of the trans-Tasman relationship aimed at restricting access to social security payments to New Zealanders in Australia.

Not all Islanders have entered Australia via New Zealand, however, and many of the early migrants were students who married and settled in Australia then sponsored their relatives to migrate. Australia's family reunion policies have enabled these early migrants to initiate chains of migration in which the later migrants sponsored still more family members. Others have entered on short-term visas and become overstayers, working mainly in rural areas in the eastern states (see Schubert, this volume). In Australia today the largest group of Pacific immigrants are from Fiji, mainly Indo-Fijians who have entered as skilled migrants, followed by Samoans, Tongans and Cook Islanders (Stahl and Appleyard 2007, 40).

\section{Movement to North America}

As in the case of New Zealand, the history of Pacific migration into the USA has been shaped by its colonial ties and ongoing political associations (Ahlburg and Levin 1990). The USA controlled American Samoa from 1900 and since 1951 these islands have been an unincorporated territory of the USA, granting American Samoans the status of US Nationals and free entry to the USA, but fewer rights than American citizens. The USA also grants free access to citizens of the Federated States of Micronesia, the Republic of the Marshall Islands and the Republic of Belau (Palau), known collectively as the Compact States since 
the Compact of Free Association in 1986. In addition, Guam, which has been a US territory since 1898, has the 1950 Organic Act of Guam which gives its inhabitants US citizenship (Levin and Ahlburg 1993, 96).

Other Islanders, particularly Tongans and Samoans, have migrated to the USA by various means such as 'step migration' through American Samoa and Hawai'i. Many others had their moves to the USA facilitated by membership of the Mormon Church (Church of Jesus Christ of Latter Day Saints) and they have settled around Mormon centres in Utah and Hawai'i. Some Pacific Islanders also have been able to migrate through the Green Card lottery system. Today, Samoans are the largest Pacific population in the US, followed by Micronesians, Tongans and Fijians (Ahlburg and Song 2006, 111). ${ }^{2}$

\section{An Expanded Pacific}

The populations of Pacific Islanders in these three main destination countries are large relative to the populations remaining in the islands. Attempts to describe this diasporic spread include Gerard Ward's discussion of the 'expanding worlds' of Pacific Islanders (1997) and Hau'ofa's depiction of the 'enlarged world of Oceania' and 'expanded Oceania' $(1998,392)$. More recently, Manuhuia Barcham has proposed the term 'new Polynesian triangle' to describe the population that stretches beyond the Pacific to North America, New Zealand and Australia (2005; see also Barcham, Scheyvens and Overton 2007). If we extend this idea to include the mobility of people from Micronesia and Melanesia we could speak of a 'new Pacific triangle'. Macpherson and Macpherson (this volume) refer to a Samoan 'meta-culture', an idea that could be applied to other Pacific populations.

However they are described, the diasporic populations of Pacific peoples are so large, relatively speaking, and have maintained such strong links to their island homes, that they cannot be ignored in any discussion of the Pacific. The case studies presented in the remaining chapters of this book explore those ties to the islands: the multiple and complex forms of transnationalism that have developed since the first movements out of the Pacific and continue to shape the lives of Pacific peoples both at home and abroad.

These ties were first established by the early migrants who, for the most part, settled permanently in their new homes. From the start, many expressed an intention to return home, but relatively few have done so, at least not permanently, and there are now second and third generations of these populations established in the destination countries. There also has been some temporary migration, particularly to New Zealand where, as we have seen, various short-term labour schemes have been introduced. In recent years the opportunities for temporary migration have been expanding, as people with different skills - teachers, rugby players, soldiers, health workers, and so on-look globally for opportunities for mobility. Pacific Islanders now live and 
work in places such as the Gulf States, the Middle East and Japan (Voigt-Graf 2007, 151; see also Voigt-Graf, Iredale and Khoo 2007). This movement of skilled workers and professionals adds to the concerns about 'brain drain' that have also been expressed in relation to longer-term migrants (Connell 2004, 2006b, 2007).

Whether they move away from the islands temporarily or permanently, few Pacific migrants do not maintain ties with their homelands and there is an ongoing flow of people, money, goods, ideas and so on, between those at home and overseas, and across the diaspora. This flow is captured by the term transnationalism, which has become a central preoccupation of scholars of migration worldwide in recent years.

\section{Transnationalism: The Wider Literature}

Transnationalism was originally a concern of international economists describing flows of labour and capital but was later applied more broadly, including within the field of migration and diaspora studies. Although even the earliest studies of migration noted that some migrants maintained ongoing connections with their homelands, it was not until the late 1980s that such connections developed to the extent that they became the focus of research and 'transnational' studies came to the fore. Cheaper and faster transport and developments in information and communications technologies have enabled people to move more easily, send money and goods more cheaply and quickly, and maintain personal connections with family and friends. These increasing options for transnational connections have a wide range of implications for the lives of both migrants and those remaining 'at home'.

Since emerging in the 1990s the literature on the transnational practices of migrants has focused primarily on individuals and families: 'how ordinary individuals live their everyday lives across borders and the consequences of their activities for sending - and receiving - country life' (Levitt and Waters $2002 a, 8)$. This focus on the relationship between transnationalism and people's everyday lives has been described by Michael Smith and Luis Guarnizo (1998) as 'transnationalism from below', in contrast to 'transnationalism from above' in arenas such as the global media, political institutions, global financial organisations and transnational business.

Studies of transnational migrants examine aspects of their lives including their complex ties with kin; their economic connections to the homeland, particularly remittances; their citizenship; their involvement in political and ethnic organisations; and their ties through religion and 'cultural' elements such as music, food and art. In addition, research increasingly takes into account the national and international policy regimes within which transnational activities take place' (Levitt, DeWind and Vertovec 2003, 568). Thus far, however, the 
vast majority of this work on transnationalism has focused on immigrants from Caribbean, Asian, Latin American and African countries who live in the USA, Canada and Europe. The contributions to this book redress this imbalance by focusing on Pacific peoples who until now have been largely absent from discussions of transnationalism.

In the relatively short time since transnationalism became a major focus of migration studies, a great deal has been done to refine and redevelop the concepts and terminology employed. ${ }^{3}$ Levitt and Jaworsky (2007) provide an excellent overview of the transnational literature and recent developments in research, which include works on the transnational engagements of people who remain in the home country; the process of return migration; how transnationalism impacts on gender, class and race both in host and home countries; and the negative outcomes of transnationalism. This recent focus on negative outcomes is needed to counterbalance a tendency in the earlier transnational literature to celebrate transnationalism as a means for migrants to increase their opportunities, enhance their social networks and cope with the problems they faced in the host country. However, practices such as remitting can have negative outcomes, such as creating and exacerbating poverty amongst remitters, as Dennis Ahlburg (2000) noted for Pacific Islanders in the USA. Transnationalism can also make it difficult for migrants ever to feel completely 'at home' in any one place, which in turn can provoke identity crises and lead to an ongoing sense of being unsettled even among so-called 'settler migrants'. As Kalissa Alexeyeff's contribution to this volume reminds us, a further negative outcome is the 'loss and dislocation' inherent in the movement of people who visit, but then also leave-ongoing connections can also involve disconnections.

Within Pacific studies, even the earliest work on migrants' ties to their homelands considered both positive and negative outcomes. Indeed, as becomes apparent in the discussion below, this became a major focus of Pacific migration research, particularly the impact of remittances and the issue of dependency. The Pacific literature was also ahead of its time in considering both religion and gender, two of the issues that have only recently been highlighted in wider transnational research. Given the strong adherence of most Pacific migrants to churches with close ties to their counterparts in the islands, it would have been impossible to discuss Pacific transnationalism without acknowledging religion, and gender differences in remitting patterns have been noted since Paul Shankman acknowledged that women were the most frequent and reliable Samoan remitters (1976).

Recently there also has been a growing critique of the 'nation' in transnationalism; of the idea that in the context of transnationalism social relations are organised around and shaped by the nation-state (Levitt and Jaworsky, 2007). The idea of 'post-national' is sometimes used to indicate that 'while the nation-state still 
plays a part in the development options available to individuals and groups in the modern world it is merely one of many 'actors' that impacts on peoples' lives and developmental options available to them' (Barcham 2005, 3). In Pacific studies this idea of looking beyond national borders is not new, as seen in the idea of 'world enlargement' proposed by Hau' ofa (1993a, 1998). Hau'ofa conceptualises Pacific peoples as interacting across national borders and describes their informal movement along ancient routes drawn in bloodlines invisible to the enforcers of the laws of confinement and regulated mobility' (1993a, 11). While Hau'ofa's intent was to challenge Western views of the Pacific, it can also serve to challenge models of transnationalism that focus on distance, separation, and the boundedness of nation-states.

\section{Pacific Transnationalism}

The process of world enlargement as described by Hau'ofa has created a vast, complex and complicated network of ties between Pacific individuals, groups and institutions which stretches to the triangle formed by the USA, New Zealand and Australia, and far beyond that to the Pacific peoples living in many countries of the world today. Indeed, the movements of some Islanders across multiple national and state borders, with or without the required visas and work permits, inspired the author of one of the chapters in this book to suggest that such people's perceptions of their movements might best be characterised by 'border-irrelevance' (Mark Schubert, personal communication, 10 October 2007). In her critique of Pacific migration studies, Sa'iliemanu Liliomaiava-Doktor has emphasised the need to recognise 'movement as a social or cultural act' (2009, 3) and she discusses recent analyses by Pacific Islander scholars of indigenous concepts of space and movement which focus on social connections (see also her chapter in this volume).

Although there is still much to be done to incorporate such indigenous perspectives into theories of population movement, the concept of transnationalism, with its implied transcendence of national borders, seems more useful in many respects than 'migration' which, as Lilomaiava-Doktor points out, 'might imply severance of ties, uprootedness, and rupture' $(2009,1)$. Retaining the term transnationalism also reminds us that to some, particularly governments, national borders are highly relevant and well guarded. The transnational movement of people, money and goods is regulated and controlled, and the borders involved often also represent 'cultural' borders to be encountered and negotiated as part of population movement. The form of transnationalism with which Pacific peoples typically engage is shaped by this awkward relationship between state-imposed borders and cultural differences, and their own perceptions of social relatedness that transcend national boundaries and emphasise reciprocity, kinship and cultural identity; themes that are discussed in the following chapters of this book. The case studies presented in the chapters 
highlight the multidirectional nature of Pacific transnationalism and its influences, which result in populations in both home and host nations undergoing continual processes of cultural transformation.

The literature on Pacific migration comprises two main bodies of work. The first is concerned with the experiences of migrants in the destination countries, with a particular focus on identity issues and giving only limited consideration of migrants' ties to their homelands. The other body of work addresses the twin issues of remittances and aid as factors in the economies of Pacific nations, and so is interested in migrants primarily as remitters. As Barcham has noted:

The problem lies, however, in the sad fact that these two bodies of literature talk past each other and so do not engage with their common concern - the impact of migration and movement on the well-being and welfare of Polynesian individuals and communities. In a sense, each body of literature is discussing part of the issue and in doing so they are missing many of the positive and dynamic developments occurring in Polynesian communities across the Pacific $(2005,2)$.

There have been some exceptions in recent years, which are discussed later in this chapter, but for the most part Barcham's observation still holds true. Clearly, there is a need not only to draw these two bodies of work together but also to expand our understanding of Pacific transnationalism beyond remittances, given that it takes such diverse forms and occurs in such a wide range of contexts. The papers in this book do just that, providing a more detailed picture of Pacific peoples' transnational practices and the impact of these practices on their experiences both 'at home' and abroad.

Pacific transnationalism certainly fits descriptions of transnationalism as influencing migrants' everyday lives and involving individuals, groups, institutions and even governments. People move between their host nations and countries of origin, and within the diaspora, for many different reasons: to visit family; to attend special family events such as weddings, funerals and the birth of children; to attend church events or national celebrations; to visit different overseas communities to raise funds for various purposes; for sporting events; for employment; or for education. Money and goods circulate within these webs of connections and people also maintain transnational ties through phone calls, letters, email, internet forums and networking sites, video and DVD recordings of events, and in many other ways. The extent of engagement in transnational practices varies between individuals and each engages differently according to their life-stage, particular life experiences and circumstances, and the situation of the people, groups and institutions with whom they are connected.

A common finding in the Pacific literature is that as more members of an individual's family migrate and as elderly kin in the islands pass away, 
transnational connections can dwindle. However, if what I have called intradiasporic transnationalism (Lee 2007a) is taken into account, transnational ties can continue across the diaspora even if ties to the homeland diminish. Within the broader literature on transnationalism these kinds of connections have only recently been discussed and some researchers have moved beyond simply looking at links between country of origin and country of settlement to look at 'other sites around the world that connect migrants to their conationals and coreligionists' (Levitt and Jaworsky 2007, 131). More research is needed on this issue for Pacific Islanders if the full breadth of their transnational engagements is to be taken into account.

It is important to note that not all migrants maintain transnational connections and there are certainly Pacific migrants who make conscious decisions not to participate in transnational activities. However, given the central importance of kin to Pacific peoples it is difficult to withdraw completely from the transnational networks that have been developed. Such withdrawal would entail refusing to uphold obligations to kin, which could in turn lead to exclusion from the kinship group and local community, and therefore from the social networks that not only make demands on members but also provide important sources of support. For most Pacific migrants the very process of migration is motivated in part by a desire - or sense of obligation - to support kin in the homeland, so, in a sense, transnationalism is perceived as an inherent element of migration.

In the case of migrants' children, the 'second generation', there is more scope for withdrawing from transnational activities and, as will be discussed below, many do not maintain direct ties to their parents' homelands. Nevertheless, I have identified processes of indirect transnationalism: if migrants or their children retain any involvement with members of their ethnic group in the host nation they are likely to be part of a web of transnational ties even without direct involvement with the home nation (Lee 2007a). For example, they may participate in and contribute to ceremonial events in the diaspora, such as weddings and funerals, at which gift exchanges occur that involve the transnational movement of people, money and goods. They may donate money to their church, which sends some of the collected donations to a church in the islands, or funds volunteers to travel to the islands to help build a new church or otherwise contribute their labour, or raises money to send youth groups 'home'. They may attend social events at which money is donated through various activities, such as performances from fundraising groups visiting from the homeland and that money is also channelled back to the islands. In the case of the second generation, another common form of indirect transnationalism is when older family members request money from junior members and send it 'home' as part of the family's collective remittances. Again, more research is needed to ascertain the forms and extent of indirect transnationalism and whether in some cases we could perhaps consider it as involuntary transnationalism. 


\section{Remittances and the MIRAB Model}

Remittances have been the primary preoccupation of studies of Pacific migration and transnationalism for many years as part of a widely-expressed concern about the economic futures of many island countries. The focus has been on remittances of money and goods, and to a lesser extent on what have been referred to in the broader literature on transnationalism as 'social remittances', that is, the ideas, values, practices and even identities that move between diaspora and homeland (Levitt and Jaworsky 2007, 132). A range of factors including limited domestic resources, small land masses and geographical isolation, declining commodity prices, limited opportunities to generate income, environmental problems, government policies that create obstacles to change and the rising expectations of the population have all been cited as factors in the creation of a reliance on remittances and foreign aid in order for the small island countries to remain economically viable. This led to a focus in the 1970s on the issue of dependency, generating considerable debate about the role of remittances in the home country (Bedford 1984). A key argument was that remittances were used primarily for consumption and therefore acted as a disincentive to investment and local production, hindering development and creating a dependent relationship between those at home and the migrants (Connell 1980; and see below).

The issue of remittances has recently become a key concern in studies of transnationalism, as shifts in the world economy create increasing opportunities for labour mobility and the generation of remittances. Steven Vertovec, for example, says of remittances:

The money [that] migrants send not only critically supports families, but may progressively rework gender relations, support education and the acquisition of professional skills and facilitate local community development through new health clinics, water systems, places of worship and sports facilities. Remittances may also undermine local labour markets, fuel price increases, create new status hierarchies and generate patterns of economic dependence $(2001,575)$.

These are all issues discussed in the literature on Pacific migration and remittances from the late 1960s, and this same tension between the cost and benefits of remittances has been debated in much of the subsequent work. In the mid-1980s some of this work on the Pacific began to draw on the 'MIRAB model' developed by Geoff Bertram and Ray Watters, based on the elements of MIgration, Remittances, Aid and Bureaucracy that characterised some Pacific states. Bertram and Watters originally developed the model to describe the island states with colonial links to New Zealand (1985, 1986; Bertram 1986) and as the model gained currency it was used to describe other Polynesian and Micronesian countries with similar economic situations, even countries beyond the Pacific (Bertram 1999). 
The MIRAB model emphasises the integration of island economies with 'the mainland' (New Zealand in the initial model) and how this process 'turned the Islands from resources-based into rent-based economies' (Bertram and Watters 1986, 57). An essential element in this process was migration from the islands so that remittances could be sent to support those at home. Bertram and Watters argued that migration from the Pacific was shaped by the collective decision making of family units in order to maximise benefits to the whole group. Drawing on earlier work on Tonga by George Marcus $(1974,1981)$ they used the term 'transnational corporations of kin' to describe this process (Bertram and Watters 1985, 499). They argue that remittances are sustainable as long as 'kin corporations' continue to operate and there is a continuing flow of new migrants.

A substantial literature now exists discussing the pros and cons of the MIRAB model and the question of whether MIRAB economies are sustainable over time. Despite various critiques of the model it continues to be applied and developed to take into account changes within Pacific economies and the importance of social relationships and personal agency (e.g. Bertram 2006; Evans 1999, 2001; Fraenkel 2006; Stahl and Appleyard 2007).

\section{Remittances: Other Perspectives}

It is understandable that remittances became the central preoccupation of the literature on Pacific migrants and their ties to their homelands, given that many of the Pacific economies have been significantly bolstered by this income. Tonga and Samoa, for example, have been among the top remittance earning countries of the world for some years and their economies would be in danger of collapse if there were any drastic decline in remittance income. For this reason, debates on the sustainability of remittances continued to dominate the literature on Pacific migration throughout the 1990s. This work was concerned with a number of questions, including:

- Who sends remittances?

- What kinds of remittances are sent?

- To whom are remittances sent?

- How much do individuals and families send?

- How reliant on remittances are the Pacific nations?

- What channels are being used to send remittances?

- What purposes do remitters have for the money and goods they send?

- How are remittances actually used?

- What is the impact of remittances on the receiving nations?

- Do remittances decline over time?

- What kinds of policies relevant to remittances should be in place in home and host nations? 
A substantial body of work now exists that addresses these questions and a report by John Connell and Richard Brown, Remittances in the Pacific (2005), provides a useful overview of the findings to date in relation to the questions listed above. In their conclusion they return to the broader context of migration, in which transnational ties such as remittances play a key role, and they argue

that maximising the benefits of international migration is crucial since it is highly valued throughout the region for social and economic reasons. As long as considerable economic challenges face island states, as their population growth rates remain above world averages, as development prospects are few, as the possibility of declining aid becomes more apparent, and as expectations rise, the ability to migrate will be crucial (Connell and Brown 2005, 55). ${ }^{4}$

The kinds of issues that have been discussed in the literature on Pacific remittances for many years are now affecting Fiji, which is rapidly moving towards the situation in countries like Tonga and Samoa, where a large proportion of households have members living overseas who send remittances home (Stanwix and Connell 1995). As Mohanty (2006) points out, this has been occurring only since the late 1990s, so this has been a remarkably rapid transformation of Fiji's economy. Fiji is now dealing with including increasing reliance on remittances and how they are being used, as well as the issues of 'brain drain' and associated slowing of the 'development' processes.

\section{The Uses of Remittances}

An ongoing debate in the literature on Pacific migration, over whether remittances help or hinder economies, has led to a body of research into how remittances are used. As we have seen, on one side of this debate is the view that remittance-dependence is unsustainable and hinders the expansion of the local economy; on the other is the position characterised by the MIRAB model, which sees these economies as sustainable so long as migration, remittances and aid continue but views self-sustainability as impossible. Associated with the debate is the question of whether remittances are used for 'unproductive' purposes or contribute to savings and investment in the island economies (Poirine 1998; Ward 1997).

In the Pacific today, remittances are being used for a wide range of purposes that go well beyond simple consumption, although consumption certainly remains significant, particularly for families entirely reliant on remittances for income. Remittances are used for purposes as varied as paying debts, purchasing airfares, paying school fees and church donations, building homes and business premises, contributing to the costs of events such as weddings and funerals, and facilitating investment in businesses. In addition, it has become clear that remittances are not sent simply to 'help the family' but also for migrants' own benefit: to maintain 
land rights, for personal investment and to support their plans for retirement. Remittances are also used in status building, as when money that is sent to kin is presented to institutions such as churches, schools and sports groups, to signal that the family is generous and prosperous (James 1997).

Remittances are also facilitating a growing informal economy; for example, goods are sent by migrants for resale through second-hand markets. Brown and Connell (1993) studied Tongan flea-markets and found that they have opened up new ways for individuals to generate income and are a means of contributing to the domestic economy through investment. Some who were selling in the markets were developing business-like arrangements with their overseas kin, sending and receiving goods to build up profits (see also Besnier 2004; James 2002). Similarly, Ward has reviewed studies that 'proved support for the argument that the emergence of trans-national families as economic units can be a very effective form of business organisation for the Pacific Islands' $(1997,193)$. Ward points out that the arrangements between migrants and kin at home are made through the informal remittance system; for example, sending goods for local businesses in the islands and return trade of agricultural products for niche markets of Pacific Islander communities overseas. Such arrangements are not recorded in formal trade statistics, making it difficult to assess how island economies are actually faring. The informal economy also makes it impossible to ascertain the full extent of remittances. Brown and Foster found for Tongan and Samoan migrants in Australia in the early 1990s that their unrecorded remittances comprised 57 per cent of total remittances $(1995,32)$, and Ken'ichi Sato's survey of other studies from the 1980s and 1990s shows estimates of unrecorded remittances as percentages of total remittances varying from 23-41 per cent $(1997,174)$.

\section{The Sustainability of Remittances}

The question of remittance decline has been of concern to researchers whether or not they use the MIRAB model, but there has been considerable disagreement about whether this is likely to occur. A key issue that has been identified is the economic situation in the destination country; for example, in his research on Samoans in New Zealand Cluny Macpherson $(1990,1992)$ has shown that a decline in the national economy and the effects of government policies favouring skilled migrants can contribute to a decline in remittances. Connell also argues that remittances are likely to decline if migration levels drop, adding:

However, if the economies of the metropolitan countries are restructured to reduce employment opportunities for unskilled labour, if unemployment increases or there is political opposition to increased migration levels, the tasks of sustaining migration and remittances will be extremely difficult $(1990,11)$. 
Decreasing migration levels can have a significant impact; Ahlburg points out that 'the continued flow of new migrants is critical to the continued growth of remittances' $(1991,3)$. Ahlburg also sees the aging of current migrants and increasing migration of entire families as potentially contributing to remittance decline. He discusses the difficulty of home governments instituting policies to encourage remittances and suggests:

Perhaps the best the home country can do is create a good macroeconomic environment where domestic investment opportunities can develop. Such an environment is supportive rather than regulative. Political stability also seems to be important if funds are to flow to the home country $(1991,53)$.

A further factor that must be considered in relation to the sustainability of remittances is the willingness of migrants to continue to contribute financially to their homelands (Spoonley 2001). As Paul Spoonley points out, migrants may decide to prioritise investment in their own welfare and success over their obligations to kin and community. A decade earlier, Kerry James questioned the MIRAB model's assumption that 'transnational family enterprises' would help sustain remittances, arguing that kin networks could continue without remittances, by obligations being met through 'trading partnerships, overseas hospitality to migrant workers, and other forms of help' $(1991,2)$.

Although some studies have shown that many individuals and families maintain remarkably high levels of remittances even 20 years after migration (e.g. Brown and Foster 1995), there are other factors involved in the overall picture of remittance sustainability. The demand for remittances is increasing as the cost of living in the islands increases and people desire more consumer goods, while at the same time communities in the diaspora are growing and local demands on people's resources are increasing, creating a tension between obligations to local community and people in the islands. Some migrants' remittances decline or even cease as family members migrate and if migrants themselves do not plan to return to live in the islands this can also reduce their tendency to remit. The literature on the sustainability of remittance shows that all of these factors and more combine to influence the remittance practices of migrants, making it difficult to predict with any accuracy the future of remittances in any of the island countries.

Overall, the general consensus tends to be that remittances could be maintained for some time if current migration levels are sustained or increased, but even that will not guarantee an indefinite flow of remittances to the islands. Cathy Small sums this up in relation to Tonga:

Remittances will eventually both slow and transform in kind, and both of these processes will have to do with the larger demographic and 
economic factors in which the global family has come to be embedded. Neither emphasizing Tongan traditions nor bolstering Tongan identity will keep remittances flowing or family ties strong, for the foundations of Tonga's transnational families and economies lie elsewhere - in global processes occurring outside Tonga (1997, 198).

The long term sustainability of remittances must also be considered in relation to the second generation, who, when they remit at all, tend to do so at significantly lower levels than their parents' generation, as discussed later in this chapter. Another factor is whether temporary worker schemes are continued, as these can generate ongoing remittances. As mentioned above, these have been in place for some time in New Zealand and a similar scheme was introduced in Australia in 2009, but they are subject to the whim of changing government policies. $^{5}$

A final point to be made in relation to remittances is that most of the literature on this topic for the Pacific is concerned only with money and goods sent from the diaspora to the homeland. However, as Connell and Brown remind us:

In almost every context remittances are bi-directional, and the remittances sent from home countries are most likely to be composed of goods of various kinds, usually foods and handicrafts...In some cases these represent altruistic gifts associated with the essential element of reciprocity; in others they stem from self-interest, pump primers for continued remittances from destination countries $(1995,11)$.

James observes that among Tongans, the contraflows of goods continually remind migrants of their economic and social obligations toward the home-based members of family networks' $(1997,3)$. Tongan goods are used within the migrant population, including as gifts to widen the support network and help them with opportunities for social mobility, and so, in a sense, reciprocate the money and goods sent by that population (see Addo this volume, Evans 2001). These 'contraflows' are not insubstantial and in a study of Tongan migrants in New Zealand, David McKenzie estimated that the flow of goods, and even some cash, from Tonga to these migrants equalled an average of 43 per cent of the value of their remittances to Tonga (2006).

\section{Beyond Remittances}

Little of the existing literature on Pacific migrants' transnational practices looks beyond remittances. An early exception is Evelyn Kallen's The Western Samoan kinship bridge (1982) which examines the kinship networks sustained by Samoan migrants, mainly in the USA, with Samoans remaining in the islands. Like much of the literature on the Pacific diaspora it is particularly focused on the issues of kinship and identity, but unlike many other authors, Kallen is interested in the role of transnational ties in shaping diasporic identities and experiences. 
Small's Voyages: from Tongan villages to American suburbs (1997) has a similar focus, in this case tracing the ties of a particular extended family group between members in different locations in the USA and their village in Tonga. My own work on the Tongan diaspora (Lee 2003, 2004b) also shares Kallen's concern with kinship and identity and examines how transnational ties affect migrants and their children as they negotiate the challenges of life as members of a minority 'ethnic group' in the host nations.

Another exception is the work by Macpherson on Samoan migrants in New Zealand. Over the years he has traced the changes within the Samoan community in New Zealand, particularly Auckland, describing how continued migration and ongoing ties to the homeland have gradually transformed aspects of $\mathrm{fa}^{\prime} \mathrm{a}$ Samoa (the Samoan way) in the migrant communities (1984, 1991, 1994, 2002, 2004; Macpherson and Macpherson 1999 and this volume). Macpherson has shown that over time there has been a significant shift from the early years of migration in which there were 'expatriate nodes' sending remittances and maintaining other ties with 'the center, which was, of course, the village of origin in which the family's landholdings, its chiefly title, and the core of its members resided' (Macpherson 2004, 168). Now, he argues, 'the nodes have become centers and Samoan culture has become a global one' (ibid, 179; see also Lilomaiava-Doktor this volume).

Beyond such case studies there has been little discussion of transnationalism in relation to the Pacific as a whole. Spoonley has addressed this broader issue from the perspective of transnationalism's challenge to the nation-state:

Transnational communities by their very nature further contribute to what some interpret as the destabilisation of the nation and the state. They transcend national boundaries by their activities, and their members typically have divided loyalties between their country of residence and their ethnic community, or between the countries of origin and current location. The movement of people and goods across borders, especially when those movements are undocumented and part of informal networks, confirm the increasing permeability of borders and emphasise the significance of multiple loyalties - to place of residence, place and culture of origin, to diasporic communities, and to evolving identities... We can add that the communities also change the nature of the metropolitan societies in which they reside by virtue of their transnational activities. They are one further and important element in the subdivision of the nation and the declining sovereignty of the state $(2001,84-85)$.

In a later paper, Spoonley, Bedford and Macpherson discuss the transnationalism of Pacific Islanders in New Zealand and conclude: 'The state in New Zealand has yet to grasp the significance of the transnationalism of Pacific peoples' (2003, 43). They argue that this is partly because Islanders themselves have not engaged 
fully with the possibilities of transnationalism, such as political mobilisation, and partly because of New Zealand's 'openness in both immigration and economic access' (ibid, 43). There have been changes even since their article was written, such as the response of Tongans in New Zealand to ongoing political problems in their homeland, including the public servants' strike in 2005 and a riot in Tonga's capital, Nuku'alofa, the following year. Not only did Tongans mobilise to stage public protests in New Zealand but they also rallied to pressure the New Zealand government to intervene. Nevertheless the argument that New Zealand has not grasped the significance of Pacific transnationalism holds true and could be extended to both the Australian and American governments. To give just one example, a detailed Senate report on Australia's relationship with the Pacific produced in 2003, A Pacific engaged (Foreign Affairs, Defence and Trade References Committee), did not mention the Pacific communities dwelling in Australia or their role in maintaining ties with the island nations.

There is clearly a need for more work on Pacific Islanders' 'long distance nationalism' (Fouron and Glick Schiller 2002) to explore migrants' involvement in the processes of nation-building in their countries of origin.

Long distance nationalists may vote, demonstrate, contribute money, create works of art, give birth, fight, kill, and die for a 'homeland' in which they may never have lived. Meanwhile, those who live in this homeland will recognize these actions as patriotic contributions to the well-being of their common homeland (Fouron and Glick Schiller, 2002, 173).

Pacific migrants may have not had reason to die for their countries, but they have been active for many years in a range of contexts including politics, business and the churches (see the chapters by Hoëm and Nosa in this volume). Hau'ofa pointed out that 'from their bases abroad they are exerting significant influences on their homeland' $(1994,423)$. He cites their use of media and information and communications technologies to share information and maintain contact. 'National issues are internationalized through transnational networks of a highly mobile population, making it difficult for the powers that be to keep track of, let alone contain, any social movement with tentacles spread across the globe' $(1994,423)$.

Studies of Pacific people's use of the internet support Hau'ofa's argument. The work by Alan Howard and Jan Rensel on Rotumans (2004; Howard 1999), Marianne Franklin's work on Pacific internet discussion forums (2001, 2003, 2004), and my own work on Tongans online (Morton 1999, Lee 2003, 2006b), has revealed the many ways in which Pacific Islanders scattered across the globe share information and create and maintain transnational networks. This cyber-transnationalism is constantly expanding and changing and the emergence of social networking sites such as MySpace, Facebook and Bebo, and 
video-sharing sites such as YouTube have opened up new ways for ties to be established and for networks of connections to become increasingly complex.

\section{Transnationalism and Problems in the Diaspora}

As noted earlier in this chapter, much of the literature on Pacific migration has focused on the diaspora and the issues facing migrants and their children in their new homes. ${ }^{6}$ Although much of this work acknowledges the ties that Pacific migrants maintain with their homelands, little of it examines these transnational ties in any detail, or attempts to explore in any depth the ways in which transnationalism impacts on people's lives and identities in the host countries. As yet, we know little of how people's transnational ties affect their engagements with the wider society, their interactions with others within their own communities, their family lives, or their economic situation. Ahlburg has observed that few studies have investigated the impact of remittances on the sending households and he claims that 'at least in the US, many Pacific Islander households live close to the poverty line. The payment of average remittances can force many of them into poverty and those already in poverty even deeper into poverty' (2000, 65). Ahlburg and Song (2006) later showed that overall, Pacific Islanders in the USA experienced an improvement in their economic situation in the 1980s and 1990s, which they attribute in part to gains in 'human capital' through education and employment.

Spoonley has observed problems associated with poverty in New Zealand:

there are growing pressures on communities which contain a significant proportion of work-or education-poor, and benefit-dependent households with the negative statistics that accompany such conditions. This disadvantage is now intergenerational as the costs of accessing education, housing and health increase. With a declining ability to pay, future generations are locked into a poverty cycle which even collective strategies are unable to reverse in any significant way...The growing pressure impacts particularly on the children and women of transnational communities $(2001,94)$.

Further research is needed to ascertain the relationship between economic status and transnational practices: one would assume that living in poverty reduces people's ability to remit, to travel between home and host countries, and otherwise engage transnationally, but anecdotal evidence suggests that this is not necessarily the case. There appears to be a growing disparity between those who have managed upward mobility and those living in poverty, but how does this affect their transnational ties? Or, to pose the question in reverse, how do transnational ties impact on migrants' socio-economic status? Ongoing research will be needed to assess the effects of the global economic crisis that began emerging in 2008 and which could have significant and multiple impacts on 
migrants' transnational practices. Even before this crisis there was evidence of economic status affecting mobility; for example, Spoonley (2001) reports Pacific Islanders moving to different parts of the diaspora to find work.

\section{Return Migration}

Another form of movement that can be motivated by low socio-economic status is return migration. Connell has found that there is generally a low level of return migration in the Pacific and that 'return migration is often an admission of failure' (1990, 19; see also Connell 2009). He observed that those who do return often have problems readjusting and tend to remain in urban areas. Macpherson (1985) also noted problems of readjustment for the few Samoans who return, particularly younger people who had spent most of their lives overseas. He argues that the low rate of return is due to migrants' desire to remain near their adult children and their families overseas and financial considerations such as lack of jobs and low wages. Shankman (1993) concludes that Samoan return migration has been insignificant when compared with movement out of the islands. He adds that if many migrants did decide to return it would create significant problems for Samoa's economy, a point that rings true for other Pacific countries that have experienced emigration and rely on remittance income.

In a recent paper on Samoan return migration Macpherson and Macpherson (2009) note that more migrants began returning to retire in Samoa when New Zealand allowed them to draw on their New Zealand pensions from the islands. However, they also show that many return migrants do not settle permanently in Samoa, but go back to New Zealand after a period living in Samoa, or move between the two locations at intervals. This tendency to re-migrate was also found by Maron and Connell (2008), in their study of returnees in a village in Tonga which showed that half of the return migrants interviewed intended to return overseas.

Ahlburg and Brown (1998) investigated migrants' intentions to return home in a study of Tongans and Samoans in Australia in 1994. Previous studies had shown that those intending to return home tend to remit more and this was confirmed by their study, although intention to return does not necessarily lead to actual return. Overall they found that only around 10 per cent intended to return, and another group (23 per cent for Tongans and 38 per cent for Samoans) were undecided. Ahlburg and Brown conclude that the return of overseas migrants is not a major channel for the acquisition of human capital for Tonga and Samoa' $(1998,131)$. The issue of human capital return is also discussed in the work on health professionals by Connell and Brown mentioned earlier in this chapter, and by Connell in his paper in this volume. Connell's paper shows that even for returning professionals, re-migration is a common outcome. 
The practice of returning children and adolescents to their parents' homelands for periods of time is a particular form of return migration that has received only limited attention in Pacific studies and the wider literature on transnationalism (Lee 2009). Macpherson (1985) observed this for Samoa and Kerry James first reported the practice in Tonga in the early 1990s. She argued that it was a way to confirm kinship ties and 'an attempt to sustain future remittances' $(1991,17)$. However, she expressed a concern about this practice, reiterated in her study of fostering on a small island in Vava'u:

Some relationships appeared to be so highly subject to change and so peripatetic that I came to wonder where the loyalties of the young will ultimately lie, and whether the children will feel called upon to support either set of parents. Thus, while children are sent as remittances, to ensure social security for themselves through confirming kinship bonds and also possibly to become effective second-generation remitters because of those bonds, I doubt in many cases that the Tongan notion of 'ofa (love, generosity) will be successfully instilled into the younger generation of migrants. Instead, they are likely to get more clearly the message of self-interest, of economic individualism, which also underlies the actions of their parents (James 1993, 369-370).

James also acknowledges the strain on people in Tonga, particularly older people, who have to take on these children and youths in a situation where many of the older forms of social control have been removed or rendered increasingly ineffective' $(1991,22)$.

Some of the children who are sent to Tonga from the diaspora are requested by family in Tonga and may stay for long periods and be welcomed into the household; most commonly these are grandchildren. Others, such as teenagers sent home because their parents are concerned about their behaviour overseas, may be accepted only because the family in Tonga feels obliged, and they can be resented (Lee 2009). Their time in Tonga is another case of what could be described as involuntary transnationalism. James has noted that 'among the data lacking from studies of Tongans overseas is an estimation of the degree of loyalty to people in Tonga that exists among second-generation migrants who have lived in Tonga for a time' (James 1997, 21). My own research indicates that the experience of being sent to Tonga for periods of time can have diverse outcomes in terms of the transnational ties maintained on return overseas, but that few who do experience this wish to live in Tonga permanently (Lee 2009).

\section{The Second Generation}

Beyond these few studies of migrants' children being returned the parents' countries of origin there is very little work on the transnational ties of the second generation. Most of the work on the children of Pacific migrants has been within 
the body of work mentioned above, which focuses on issues of identity and adaptation in the diaspora. In the broader literature on transnationalism there also has been a neglect of the second generation until recently (Lee 2008). The first collection of papers on this topic, edited by Peggy Levitt and Mary Waters (2002b) focuses on migrants in the USA, mainly from Asian and Caribbean countries, and the authors agree that transnational ties tend to be weaker in the second generation. In a review of the literature on transnationalism, Levitt and Jaworsky conclude that 'transnational activities will not be central to the lives of most of the second or third generation, and they will not participate with the same frequency and intensity as their parents' $(2007,134)$.

James' work on the return of children to Tonga, discussed above, is largely concerned with the impact of this practice on the sustainability of remittances. In another study that mentions remittances in relation to migrants' children, Loomis found that in 1985 between 55 and 82 per cent of Cook Islanders born in the islands regularly remitted, but only 20 per cent of New Zealand-born did so (1990 cited in Ahlburg 1991, 7). Similarly, Brown and Walker (1995) found for a small sample of New Zealand-born Samoans that on average their remittances were only about 30 per cent of average first generation levels. In general, however, the literature on Pacific remittances ignores the second generation, or simply assumes they will remit at lower levels than their parents but does not pursue the implications of this.

My own recent research on second generation Tongan transnationalism has confirmed that, at least in the Tongan case, remittances and other transnational ties are much weaker for migrants' children (Lee 2004a, 2006a, 2007a, 2007b). Macpherson and Macpherson (this volume) report a similar weakening of ties for the second generation of Samoans in New Zealand. Although they are weaker, some ties do remain, and focusing on remittances can detract from the bigger picture of second generation transnationalism, which is more likely to involve visits, phone calls, and electronic communication than sending money or goods. It is also more likely to involve intradiasporic ties, particularly since online discussion forums and networking sites have facilitated easy communication with Pacific Islanders anywhere in the world.

Much is yet to be learned about the transnational activities of members of the second generation of Pacific peoples overseas, including how their ties may change throughout their life-cycle and in response to events both in their parents' homelands and their country of birth. Most Pacific populations have been established overseas for long enough that there are now more members who were born in the host country than in the home islands, so it is increasingly important to include them in discussions of Pacific transnationalism. 


\section{Conclusion}

The transnational ties established by Pacific migrants during their post-war migrations to New Zealand, the USA, Australia and elsewhere remain strong today. Cheaper, faster transport and developments in information and communications technologies have intensified these ties but they are still largely kin-based connections, with additional links through institutions such as churches and schools, and assorted other connections through villages, businesses, political groups and so on.

Over a decade ago, Ward observed: 'how relations between the home and expatriate communities of different groups will develop in future decades remains a matter for speculation' (Ward 1997, 192). Since then we have learned a great deal more about those relations, although as I have shown there has been a predominance of research into remittances rather than other forms of transnational ties. Even so, the literature on Pacific transnationalism was ahead of its time in some ways: paying attention to issues of class, gender and religion from the outset, recognising the more negative outcomes of transnationalism, and addressing the role of remittances. Yet the wider literature on transnationalism rarely mentions the Pacific and until recently scholars of Pacific migration made little use of the concept of 'transnationalism' except in the context of 'transnational kin corporations'. More engagement with the broader literature on transnationalism will bring new approaches and insights to the work on the Pacific, and raise the profile of Pacific transnationalism within that broader literature.

Pacific transnationalism is a topic of growing importance, tied as it is to the very future of Pacific countries. Early in the $21^{\text {st }}$ century many of those countries face an uncertain future, with growing economic woes, political tensions, the impact of climate change, continuing depopulation in some cases and shifts in international relations, including changes to immigration policies in destination countries. Any issues facing Pacific peoples must be discussed in the context of both the islands and their diasporas, taking the processes of 'world enlargement' and transnationalism into account. Research on remittances will remain salient in the Pacific and while much has already been achieved there is still more to learn about issues such as the impact of remittances on the senders, the relationship between socio-economic status in the diaspora and the practice of remitting, and 'contraflows' from the home countries. In addition, a broader focus is needed to take into account the many other elements of transnationalism; issues to be explored include individuals' fluctuations in transnational engagements, intradiasporic and indirect forms of transnationalism, return migration and the transnationalism of the second generation. The chapters that follow address some of these issues and open up even more possibilities for future research. 


\section{References}

Ahlburg, D. 1991. Remittances and their impact: A study of Tonga and Western Samoa. Pacific Policy Paper 7. Canberra: National Centre for Development Studies.

- 2000. Poverty among Pacific Islanders in the United States: Incidence, change and correlates. Pacific Studies 23 (1/2): 51-74.

Ahlburg, D. and R. Brown. 1998. Migrants intentions to return home and capital transfers: A study of Tongans and Samoans in Australia. Journal of Development Studies 35 (2): 125-51.

Ahlburg, D. and M. Levin. 1990. The north east passage: A study of Pacific Islander migration to American Samoa and the United States. Canberra: National Centre for Development Studies

Ahlburg, D. and Y. N. Song. 2006. Changes in the economic fortunes of Pacific Islanders in the USA in the 1990s. Asia Pacific Viewpoint 47 (1): 109-21.

Barcham, M. 2005. Post-national development: The case of the 'new Polynesian triangle'. CIGAD Briefing Notes. Palmerston North: Centre for Indigenous Governance and Development.

Barcham, M., R. Scheyvans, and J. Overton. 2007. Rethinking Polynesian mobility: A new Polynesian triangle. Centre for Indigenous Development Working Paper Series. http://cigad.massey.ac.nz/publications.htm (accessed 14 December 2007).

Basch, L., N. Glick Schiller, and C. Szanton Blanc. 1994. Nations unbound: Transnational projects, postcolonial predicaments, and deterritorialized nation-states. Pennsylvania: Gordon and Breach.

Bedford, R. 1984. The Polynesian connection: Migration and social change in New Zealand and the South Pacific. In Essays on urbanisation in South East Asia and the Pacific, ed. R. Bedford, 131-41. Christchurch: University of Canterbury.

Bedford, R., E. Ho, V. Krishnan and B. Hong. 2007. The neighborhood effect: The Pacific in Aotearoa and Australia. Asian and Pacific Migration Journal 16 (2): 251-69.

Bertram, G. 1986. 'Sustainable Development' in Pacific Micro-economies. World Development 14 (7): 809-22.

- 1999. The MIRAB model twelve years on. The Contemporary Pacific 11 (1): 105-38.

- 2006. Introduction: The MIRAB model in the twenty-first century. Asia Pacific Viewpoint 47 (1): 1-13. 
Bertram, G. and R. Watters. 1985. The MIRAB economy in South Pacific microstates. Pacific Viewpoint 26 (3): 497-519.

-.1986. The MIRAB process: Earlier analyses in context. Pacific Viewpoint 27 (1): 47-59.

Besnier, N. 2004. Consumption and cosmopolitanism: Practicing modernity at the second-hand marketplace in Nuku'alofa, Tonga. Anthropological Quarterly 77 (1): 7-45.

Brown, R. 1994. Migrants' remittances, savings and investment in the South Pacific. International Labour Review 133: 347-67.

-.1995. Hidden foreign exchange flows: Estimating unofficial remittances to Tonga and Western Samoa. Asian and Pacific Migration Journal 4 (1): 35-54.

-1997. Estimating remittance functions for Pacific Island migrants. World Development 25 (4): 613-26

- 1998. Do migrants' remittances decline over time? Evidence from Tongans and Western Samoans in Australia. The Contemporary Pacific 10 (1): 107-51.

Brown, R. and J. Connell. 1993. The global flea market: Migration, remittances and the informal economy in Tonga. Development and Change 24: 611-47.

- 2004. The migration of doctors and nurses from South Pacific Island nations. Social Science and Medicine 58: 2193-210.

- 2006. Occupation-specific analysis of migration and remittance behaviour: Pacific Island nurses in Australia and New Zealand. Asia Pacific Viewpoint 47 (1): 135-50.

Brown, R. and J. Foster. 1995. Some common fallacies about migrants' remittances in the South Pacific: Lessons from Tongan and Western Samoan research. Pacific Viewpoint 36 (1): 29-45.

Brown, R., J. Foster, and J. Connell. 1995. Remittances, savings and policy formation in Pacific island states. Asian and Pacific Migration Journal 4 (1): 169-86.

Brown, R. and B. Poirine. 2005. A model of migrants' remittances with human capital investment and intrafamilial transfers. International Migration Review 39 (2): 407-38.

Brown, R. and A. Walker. 1995. Migrants and their remittances. Results of a household survey of Tongans and Western Samoans in Sydney. Sydney: Centre for South Pacific Studies.

Chand, S. 2005. Labour mobility for sustainable livelihoods in Pacific Island states. Pacific Economic Bulletin 20 (3): 63-76. 
Connell, J. 1980. Remittances and rural development: Migration, dependency and inequality in the South Pacific. In National Centre for Development Studies Occasional Paper No. 22. Canberra, The Australian National University.

—. 1990. Modernity and its discontents: Migration and Change in the South Pacific. In Migration and Development in the South Pacific. Pacific Research Monograph No. 24, ed. J. Connell, 1-28. Canberra: The Australian National University.

- 2002. Paradise left? Pacific Island voyagers in the modern world. In Pacific diaspora: Island peoples in the United States and across the Pacific, ed. P. Spickard, J. Rondilla, and D. Hippolite Wright, 69-86. Honolulu: University of Hawai'i Press.

- . 2004. The migration of skilled health professionals: From the Pacific Islands to the World. Asian and Pacific Migration Journal 13 (2): 155-77.

—. 2006a. Migration, dependency and inequality in the Pacific: Old wine in bigger bottles? (Part 1). In Globalisation and governance in the Pacific Islands, ed. S. Firth, 59-80. Canberra: ANU E Press.

-. 2006b. Migration, dependency and inequality in the Pacific: Old wine in bigger bottles? (Part 2) In Globalisation and governance in the Pacific Islands, ed. S. Firth, 81-196. Canberra: ANU E Press.

-. 2007. At the end of the world: Holding onto health workers in Niue. Asian and Pacific Migration Journal 16 (2): 179-98.

—. 2009. Bittersweet home? Return migration of skilled workers in the South Pacific. In Return migration of the next generations: twenty-first century transnational mobility, ed. D. Conway and R. Potter, 139-60. Aldershot: Ashgate.

Connell, J. and R. Brown. 1995. Migration and remittances in the South Pacific: Towards new perspectives. Asian and Pacific Migration Journal 4 (1): $1-33$.

- 2004. The remittances of migrant Tongan and Samoan nurses in Australia. Human Resources for Health 2 (2): 1-21.

-. 2005. Remittances in the Pacific: An overview. Manila: Asian Development Bank.

Connell, J. and G. McCall. 1989. South Pacific Islanders in Australia. Research Institute for Asia and the Pacific Occasional Paper 9. Sydney: University of Sydney.

Department of Labour. 2007. The recognised seasonal employer work policy. New Zealand Department of Labour. 
http://www.dol.govt.nz/initiatives/strategy/rse/index.asp (accessed 2 May 2008).

Evans, M. 1999. Is Tonga's MIRAB economy sustainable? A view from the village and a view without it. Pacific Studies 22 (3/4): 137-66.

- 2001. Persistence of the gift. Tongan tradition in transnational context. Waterloo Wilfred Laurier University Press.

Foreign Affairs, Defence and Trade References Committee. 2003. A Pacific engaged: Australia's relations with Papua New Guinea and the island States of the south-west Pacific. Canberra: Australian Government

Fouron, G. and N. Glick Schiller. 2002. The generation of identity: Redefining the second generation within a transnational social field. In The changing face of home: The transnational lives of the second generation, ed. P. Levitt and M. Waters, 168-208. New York: Russell Sage Foundation.

Fraenkel, J. 2006. Beyond MIRAB: do aid and remittances crowd out export growth in Pacific microeconomies? Asia Pacific Viewpoint 47 (1): 15-30.

Franklin, M. 2001. Postcolonial subjectivities and everyday life online. International Feminist Journal of Politics 3 (3): 387-422.

—. 2003. I define my own ethnicity: Pacific articulations of 'race' and 'culture' on the internet. Ethnicities 3 (4): 465-90.

- 2004. Postcolonial politics, the internet, and everyday life: Pacific traversals online Abingdon: Routledge.

Glick Schiller, N., L. Basch, and C. Szanton Blanc. 1992. Towards a transnational perspective on migration: Race, class, ethnicity, and nationalism reconsidered. Vol. 645. New York: Annals of the New York Academy of Sciences.

- 1995. From immigrant to transmigrant: Theorizing transnational migration. Anthropological Quarterly 68 (1): 48-63.

Hannan, K. 2006. Fiji: Sugar and sweatshirts, migrants and remittances. In Globalisation and governance in the Pacific Islands, ed. S. Firth, 189-215. Canberra: ANU E Press.

Hau'ofa, E. 1993a. Our sea of islands. In A new Oceania: Rediscovering our sea of islands, ed. E. Waddell, V. Naidu and E. Hau'ofa, 3-16. Suva: University of the South Pacific.

- 1993b. A beginning. In A new Oceania: Rediscovering our sea of islands, ed. E. Waddell, V. Naidu and E. Hau'ofa, 126-39. Suva: University of the South Pacific.

- 1994. Thy kingdom come: The democratization of aristocratic Tonga. The Contemporary Pacific 6 (2): 414-27. 
-.1998. The ocean in us. The Contemporary Pacific 10 (2): 392-409.

Howard, A. 1999. Pacific-based virtual communities: Rotuma on the world wide web. The Contemporary Pacific 11 (1): 160-75.

Howard, A. and J. Rensel. 2004. Rotuman identity in the electronic age. In Shifting images of identity in the Pacific, ed. T. van Meijl and J. Miedema, 219-36. Leiden: KITLV Press.

Howe, K.R. 1984. Where the waves fall: A new South Sea Islands history from first settlement to colonial rule. Sydney: George Allen and Unwin.

Hughes, H. and G. Sodhi. 2006. Should Australia and New Zealand open their doors to guest workers from the Pacific? Costs and benefits. CIS Policy Monograph 72. Canberra: The Centre for Independent Studies.

James, K. 1991. Migration and remittances: A Tongan village perspective. Pacific Viewpoint 32 (1): 1-23.

- 1993. Cash and kin. Aspects of migration and remittance from the perspective of a fishing village in Vava'u, Tonga. In A World Perspective on Migration: Australia, New Zealand and the USA, ed. G. McGall and J. Connell, 359-74. Sydney: Centre for South Pacific Studies, University of New South Wales.

- 1997 . Reading the leaves: The role of Tongan women's traditional wealth and other 'contraflows' in the processes of modern migration and remittance. Pacific Studies 20 (1): 1-27.

- 2002. Disentangling the 'grass roots' in Tonga: 'Traditional enterprise' and autonomy in the moral and market economy. Asia Pacific Viewpoint 43 (3): 269-92.

Janes, C. 1990. Migration, social change and health: A Samoan community in California. Palo Alto, CA: Stanford University Press.

—. 2002. From village to city: Samoan migration to California. In Pacific diaspora: Island peoples in the United States and across the Pacific, ed. P. Spickard, J. Rondilla and D. Hippolite Wright, 118-32. Honolulu: University of Hawai'i Press.

Kaeppler, A. 1978. Exchange patterns in goods and spouses: Fiji, Tonga, and Samoa. Mankind 11 (3): 246-52.

Kallen, E. 1982. The Western Samoan kinship bridge: A study in migration, social change and the new ethnicity. Leiden: Brill.

Lee, H. 2003. Tongans overseas: Between two shores. Honolulu: University of Hawai'i Press.

-. 2004a. 'Second generation' Tongan transnationalism: Hope for the future? Asia Pacific Migration Journal 45 (2): 235-54. 
- 2004b. All Tongans are connected: Tongan transnationalism. In Globalization and culture change in the Pacific Islands, ed. V. Lockwood, 133-48. New Jersey: Pearson.

- 2006a. 'Tonga only wants our money': The children of Tongan migrants. In Globalisation, governance and the Pacific Islands, ed. S. Firth, 121-35. Canberra: ANU E Press.

- 2006b. Debating language and identity online: Tongans on the net. In Native on the net: Indigenous and diasporic peoples in the virtual age, ed.

K. Landzelius, 152-68. Abingdon: Routledge.

- 2007a. Generational change: The children of Tongan migrants and their ties to the homeland. In Tonga and the Tongans: Heritage and identity, ed. E. Wood-Ellem, 203-17. Melbourne: Tonga Research Association.

- 2007b. Transforming transnationalism: Second generation Tongans overseas. Asian and Pacific Migration Journal 16 (2): 157-78.

-. 2008. Second generation transnationalism. In Ties to the homeland: Second generation transnationalism, ed. H. Lee, 1-32. Newcastle: Cambridge Scholars Press.

-. 2009. The ambivalence of return: Second-generation Tongan returnees. In Return migration of the next generations: Twenty-first century transnational mobility, ed. D. Conway and R. Potter, 41-58. Aldershot: Ashgate.

Levin, M. and D. Ahlburg. 1993. Pacific Islanders in the United States census data. In A world perspective on Pacific Islander migration: Australia, New Zealand and the USA, ed. G. McCall and J. Connell, 95-144. Sydney: Centre for South Pacific Studies, University of New South Wales.

Levitt, P. 2001. The transnational villagers. Berkeley: University of California Press.

Levitt, P., J. DeWind, and S. Vertovec. 2003. International perspectives on transnational migration: An introduction. International Migration Review 37 (3): 565-75.

Levitt, P. and B. N. Jaworsky. 2007. Transnational migration studies: Past developments and future trends. Annual Review of Sociology 33: 129-56.

Levitt, P. and M. Waters. 2002a. Introduction. In The changing face of home: The transnational lives of the second generation, ed. P. Levitt and M. Waters, 1-30. New York: Russell Sage Foundation.

-. (eds). 2002b. The changing face of home: The transnational lives of the second generation. New York: Russell Sage Foundation. 
Lilomaiava-Doktor, S. 2009. Beyond 'migration': Samoan population movement (malaga) and the geography of social space va. The Contemporary Pacific 21 (1): 1-32.

Maclellan, N. and P. Mares. 2006. Labour mobility in the Pacific: Creating seasonal work programs in Australia. In Globalisation and governance in the Pacific Islands, ed. S. Firth, 137-71. Canberra: ANU E Press.

- 2007. Pacific seasonal workers for Australian agriculture: A neat fit? Asian and Pacific Migration Journal 16 (2): 271-87.

Macpherson, C. 1984. On the future of ethnicity in New Zealand. In Tauiwi: Racism and ethnicity in New Zealand, ed. P. Spoonley, C. Macpherson, D. Pearson, and C. Sedgewick, 107-27. Palmerston North: Dunmore Press.

- 1985. Public and private views of home: Will Western Samoan migrants return? Pacific Viewpoint 26 (1): 242-62.

—. 1990. Stolen dreams: Some consequences of dependency for Western Samoan youth. In Migration and development in the South Pacific, ed. J. Connell, 107-19. Canberra: The Australian National University.

- 1991. The changing contours of Samoan ethnicity. In Nga Take: Ethnic relations and racism in Aotearoa/New Zealand, ed. P. Spoonley, D. Pearson, and C. Macpherson, 67-86. Palmerston North: Dunmore Press.

- 1992. Economic and political restructuring and the sustainability of migrant remittances: The case of Western Samoa. The Contemporary Pacific 4 (1): 109-35.

- 1994. Changing patterns of commitment to Island homelands: A case study of Western Samoa. Pacific Viewpoint 17: 83-116

- 2002. From moral community to moral communities: The foundations of migrant social solidarity among Samoans in urban Aotearoa/New Zealand. Pacific Studies 25 (1/2): 71-93.

- 2004. Transnationalism and transformation in Samoan society. In Globalization and culture change in the Pacific Islands, ed. V. S. Lockwood, 165-81. Upper Saddle River, NJ: Pearson Prentice Hill.

Macpherson, C. and L. Macpherson. 1999. The changing contours of migrant Samoan kinship. In Small worlds, global lives: Islands and migration, ed. R. King. and J. Connell, 277-91. London: Pinter.

-. 2009. It's not quite what we expected: Some Samoan returnees' experiences of Samoa. In Return migration of the next generations: twenty-first century 
transnational mobility, ed. D. Conway and R. Potter, 19-39. Aldershot: Ashgate.

Macpherson, C., B. Shore, and R. Franco (eds). 1978. New neighbors: Islanders in adaptation. Santa Cruz Center for South Pacific Studies, University of California.

Macpherson, C., P. Spoonley, and M. Anae (eds). 2001. Tangata o te moana nui: The evolving identities of Pacific peoples in Aotearoa/New Zealand. Palmerston North: Dunmore Press.

Marcus, G. 1974. A hidden dimension of family development in the modern kingdom of Tonga. Journal of Comparative Family Studies 5 (1): 87-102.

- 1981. Power on the extreme Periphery: The perspective of Tongan elites in the modern world system. Pacific Viewpoint 22: 48-64.

Maron, N. and J. Connell. 2008. Back to Nukunuku: Employment, identity and return migration in Tonga. Asia Pacific Viewpoint 49: 168-184.

McCall, G. and J. Connell (eds). 1993. A world perspective on Pacific Islander migration: Australia, New Zealand and the USA. Sydney: Centre for South Pacific Studies, University of New South Wales.

McKenzie, D. 2006. Remittances in the Pacific. In Immigrants and their international money flows. 2005-06 Werner Sichel lecture-seminar series, Western Michigan University.

Millbank, A. 2006. A seasonal guest-worker program for Australia? Research Brief no. 16. Canberra: Parliament of Australia.

Mohanty, M. 2006. Globalisation, new labour migration and development in Fiji. In Globalisation and governance in the Pacific Islands, ed. S. Firth, 107-20. Canberra: ANU E Press.

Morton, H. 1999. Islanders in space: Tongans online. In Small worlds, global lives. Islanders and migration, ed. R. King and J. Connell, 235-53. London: Pinter.

Parliament, of Australia. 2006. Perspectives on the future of the harvest labour force. Senate Standing Committee on Employment, Workplace Relations and Education. Canberra: Commonwealth of Australia. http://www.aph.gov.au/Senate/committee/EET_CTTE/contract_labour/report/ report.pdf (accessed 11 November 2007).

Pitt, D. and C.Macpherson. 1974. Emerging pluralism: Samoan migrants in New Zealand. Auckland: Longman Paul.

Poirine, B. 1998. Should we hate or love MIRAB? The Contemporary Pacific 10 (1): 65-105. 
Portes, A. 1999. Conclusion: Towards a new world - the origins and effects of transnational activities. Ethnic and Racial Studies 22 (2): 463-77.

- 2003. Conclusion: Theoretical convergences and empirical evidence in the study of immigrant transnationalism. International Migration Review 37 (3): 874-92.

Rokoduru, A. 2006. Contemporary migration within the Pacific Islands: The case of Fijian skilled workers in Kiribati and Marshall Islands. In Globalisation and governance in the Pacific Islands, ed. S. Firth, 173-186. Canberra: ANU E Press.

Sato, M. 1997. Structure and dynamics of MIRAB societies in the South Pacific: An economic study. In Contemporary migration in Oceania: Diaspora and network. JCAS Symposium Series 3: Population movement in the modern world., ed. K. Sudo and S. Yoshida, 165-77. Osaka: The Japan Center for Area Studies.

Shankman, P. 1976. Migration and underdevelopment: The case of Western Samoa. Boulder: Westview.

- 1993. The Samoan exodus. In Contemporary Pacific societies: Studies in development and change, ed. V. Lockwood, T. Harding and B. Wallace, 156-70. Englewood Cliffs, NJ: Prentice Hall.

Small, C. 1997. Voyages: From Tongan villages to American suburbs. Ithaca: Cornell University Press.

Smith, M. and L. Guarnizo (eds). 1998. Transnationalism from below. New Brunswick: Transaction Publishers.

Spickard, P., J. Rondilla, and D. Hippolite Wright (eds). 2002. Pacific diaspora: Island peoples in the United States and across the Pacific. Honolulu: University of Hawai'i Press.

Spoonley, P. 2001. Transnational Pacific communities: Transforming the politics of place and identity. In Tangata $O$ te Moana nui: The evolving identities of Pacific peoples in Aotearoa/New Zealand, ed. C. Macpherson, P. Spoonley, and M. Anae, 81-96. Palmerston North: Dunmore Press.

Spoonley, P., R. Bedford, and C. Macpherson. 2003. Divided loyalties and fractured sovereignty: Transnationalism and the nation-state in Aotearoa/New Zealand. Journal of Ethnic and Migration Studies 29 (1): $27-46$.

Spoonley, P., C. Macpherson, D. Pearson and C. Sedgewick (eds). 1984. Tauiwi: Racism and ethnicity in New Zealand. Palmerston North: Dunmore Press. 
Spoonley, P., D. Pearson, C. Macpherson (eds). 1991. Nga take: Ethnic relations and racism in Aotearoa (New Zealand). Palmerston North: Dunmore Press.

-. (eds). 1996. Nga Patai: Racism and ethnic relations in Aotearoa/New Zealand. Palmerston North: Dunmore Press.

Stahl, C. and R. Appleyard. 2007. Migration and development in the Pacific Islands: Lessons from the New Zealand experience. Canberra: Australian Agency for International Development.

Stanwix, C. and J. Connell. 1995. To the Islands: The remittances of Fijians in Sydney. Asian and Pacific Migration Journal 4 (1): 69-87.

Vertovec, S. 1999. Conceiving and researching transnationalism. Ethnic and Racial Studies 22 (2): 447-62.

- 2001. Transnationalism and identity. Journal of Ethnic and Migration Studies 27 (4): 573-82.

- 2003. Migration and other modes of transnationalism: Towards conceptual cross-fertilization. International Migration Review 37 (3): 641-65.

Voigt-Graf, C. 2007. Pacific Islanders and the rim: Linked by migration. Asian and Pacific Migration Journal 16 (2): 143-56.

Voigt-Graf, C., R. Iredale, and S. Khoo. 2007. Teaching at home or overseas: Teacher migration from Fiji and the Cook Islands. Asian and Pacific Migration Journal 16 (2): 199-224.

Walker, A., and R. Brown. 1995. From consumption to savings? Interpreting Tongan and Western Samoan sample survey data on remittances. Asian and Pacific Migration Journal 4 (1): 89-115.

Ward, G. 1997. Expanding worlds of Oceania: Implications of migration. In Contemporary migration in Oceania: Diaspora and network. JCAS Symposium Series 3: Population movement in the modern world, ed. K. Sudo and S. Yoshida, 179-96. Osaka: The Japan Center for Area Studies.

World Bank, The. 2006. Pacific Islanders at home and away: Expanding job opportunities for Pacific Islanders through labour mobility. http://www-wds.worldbank.org/external/default/ WDSContentServer/WDSP/IB/2006/11/15/000090341_20061115095505/ Rendered/PDF/377150EAP.pdf (accessed 12 December 2007). 


\section{ENDNOTES}

1 More detailed overviews of Pacific migration can be found in Connell (1990, 2002, 2006a, 2006b), McCall and Connell (1993) Stahl and Appleyard (2007) and, for Australia and New Zealand, Bedford et al (2007).

2 In the 1990s there was a surge in Samoan migration to the US, 'increasing 70\% in the 1990s compared with $22 \%$ in the 1980s' (Ahlburg and Song 2006, 110). Shankman provides a useful overview of migration from Samoa, showing the fluctuations in numbers migrating and shifts in favoured destinations as host countries changed their immigration policies (1993; see also Janes 2002).

${ }^{3}$ Key scholars who helped to establish and shape this field of research include Linda Basch, Nina Glick Schiller and Cristina Szanton Blanc (1994; see also Glick Schiller, Basch and Blanc 1992, 1995).

Contributions from scholars such as Peggy Levitt (2001) Alejandro Portes $(1999,2003)$ and Steven Vertovec $(1999,2001,2003)$ further refined the concepts and delineated the scope of transnational research.

4 Connell and Brown also edited a special issue of the Asian and Pacific Migration Journal (1995) on 'Migration and remittances in the South Pacific'. In recent years Connell and Brown have investigated the migration of skilled health professionals from the Pacific and their remittance practices (Brown and Connell 2004, 2006; Connell 2004, 2006b; Connell and Brown 2004). Connell has also looked at the return migration of these workers (2009; this volume). Richard Brown and various colleagues have also contributed a body of work on remittances since the early 1990s examining factors such as unofficial remittances and the informal economy in the islands (Brown 1995; Brown and Connell 1993); the sustainability of remittances (Brown 1997, 1998; Brown and Foster 1995; Brown and Walker 1995; Walker and Brown 1995); and the relationship between remittances and investment (Brown 1994; Brown, Foster and Connell 1995; Brown and Poirine 2005).

5 The issue of temporary labour schemes has been discussed in Chand (2005), Hughes and Sodhi (2006), Maclellan and Mares (2006, 2007), and a report by the World Bank (2006). There have also been briefing papers for the Australian government on the topic (e.g. Millbank 2006) and a Senate inquiry into Pacific Region seasonal contract labour (Parliament of Australia 2006).

6 One of the first collections of papers was Macpherson, Shore and Franco (1978). Since then there have been several more: see, for example, the work on New Zealand in Spoonley et al (1984); Spoonley, Pearson and Macpherson (1991, 1996); and Macpherson, Spoonley and Anae (2001). The collection of papers edited by McCall and Connell (1993) looks at Pacific populations in New Zealand, Australia and the US, as does Pacific diaspora (Spickard, Rondilla and Wright 2002). There also have been studies of particular Pacific populations, with a predominance of work on Samoans, as in the work of Macpherson, mentioned above (and see Janes 1990; Pitt and Macpherson 1974; Shankman 1976). 